\title{
https://doi.org/10.46813/2021-131-171 \\ SPECTROSCOPY PECULIARITIES OF ELECTRIC ARC DISCHARGE PLASMA WITH IRON VAPOURS
}

\author{
A. Murmantsev, A. Veklich, V. Boretskij \\ Taras Shevchenko National University of Kyiv, Kyiv, Ukraine \\ E-mail: murmantsev.aleksandr@gmail.com
}

This work is devoted to spectroscopy peculiarities of electric arc discharge plasma with iron vapours. The solution of the main issue of optical emission spectroscopy, namely, selection of iron spectral lines, to study the parameters of non-uniform and non-steady-state plasma source, was considered within this paper. Specifically, the Boltzmann plots technique was used for detailed analysing of application possibility of Fe I spectral lines as well as for determination of plasma temperature. The spatial profiles of selected spectral line emission intensities were used to measure the radial distributions of plasma temperature of free-burning arc discharge between consumable electrodes at $3.5 \mathrm{~A}$.

PACS: 52.70.-m

\section{INTRODUCTION}

The plasma with iron vapours as a plasma-forming gas is of a great interests due to its numerous applications. First of all, it is important object of investigation in the gas-tungsten arc welding (GTAW) processes, in which iron vapours is originated from the molten steel anode [1]. Such vapours are also presented in the gas-metal arc welding (GMAW) due to melting of iron electrode [2].

It is naturally that such kinds of welding methods need a permanent improving or optimization due to the constant emergence of new branches of their application.

For example, a new welding method of ultrasonic wave-assisted underwater wet welding (UUWW) has recently emerged [3]. An applying the acoustic radiation force to the arc bubble as an extra retaining force is in the base of such method. The analysis of UUWW was carried out on steel plates, material of which, obviously, can be transferred into a bubble volume.

A high-speed welding process with tandem pulsed gas tungsten arcs, which employed two pulse arcs is another one novel kind of GTAW [4]. The welding speed was studied by application of such method to 304 austenite stainless steel plate.

Also in connection with the emergence of new materials for pipelines, for example, erosion-resistant high-manganese steel (HMS) [5], it is relevant to improve already known welding methods. The authors developed welding procedure on the base of consumable wire for such pipes.

In addition to the works mentioned, over the past couple of years, many more welding techniques [6-8], in the process of which the iron vapours take place, and new materials requiring special approaches $[9,10]$ have been proposed.

It is obvious, that such methods and materials need the detail investigations of plasma of such discharge kinds with aim to improving and optimization of welding procedures. The optical emission spectroscopy (OES) can be one of a potential study method of process, which occurring during welding or plasma-surface interaction $[11,12]$. Such method allows determining the main plasma parameters: temperature and electron density, ISSN 1562-6016. BAHT. 2021. №1(131)

PROBLEMS OF ATOMIC SCIENCE AND TECHNOLOGY. 2021, №1. Series: Plasma Physics (27), p. 171-175. which can be obtained, for example, by Boltzmann plot technique [13] and from spectral line width broadened due to Stark mechanisms [14], respectively. Therefore, the intensity of spectral line, emitted by discharge plasma, underlies on the base of such methods of plasma parameters determination.

In our previous works, the plasma of underwater discharge between metal, specifically, iron granules, was investigated $[15,16]$. In frame of these works the large attention was devoted to spectral lines selection and their application in plasma parameters determination.

Within this paper spectroscopy peculiarities of thermal plasma of arc discharge with admixtures of iron vapours were considered. Namely, it is made an attempting to use the previously selected Fe I spectral lines [15] in study of the parameters of non-uniform and non-steady-state plasma of electric arc between steel electrodes.

\section{EXPERIMENT}

In this investigation the free-burning electric arc discharges between electrodes, manufactured of steel $\mathrm{C} 10$, were ignited in air atmosphere at arc current of 3.5 A. As an initial step, with aim of preliminary selection of spectral lines, the spatial-integrated emission spectrum of such plasma was registered by Solar LS SDH-IV spectrometer in the spectral range of $480 \ldots 620 \mathrm{~nm}$.

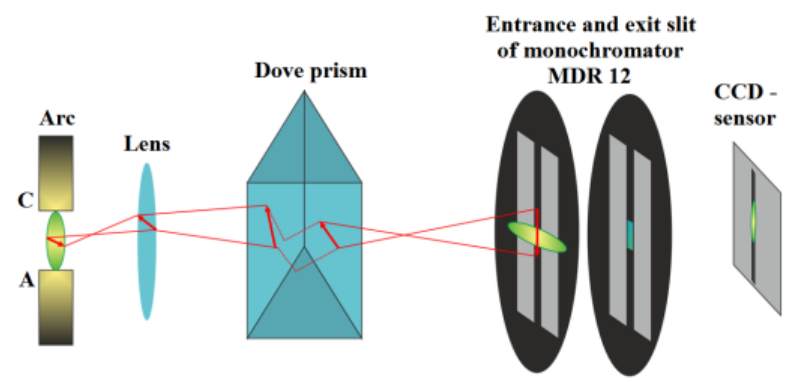

Fig. 1. The optical scheme of experimental setup, based on monochromator, for registration of spectral line emission intensities [17]

At the next step, the experimental setup on the base of monochromator MDR-12 (Fig. 1 [17]) was used for 
registration of spatial profiles of selected spectral lines emission intensities to determine the radial distributions of plasma temperature.

For the purpose of a detailed study of the contours of spectral lines with a high spectral resolution, the previous experimental setup could be supplemented with a FabryPerot interferometer (FPI) in the optical scheme (Fig. 2).

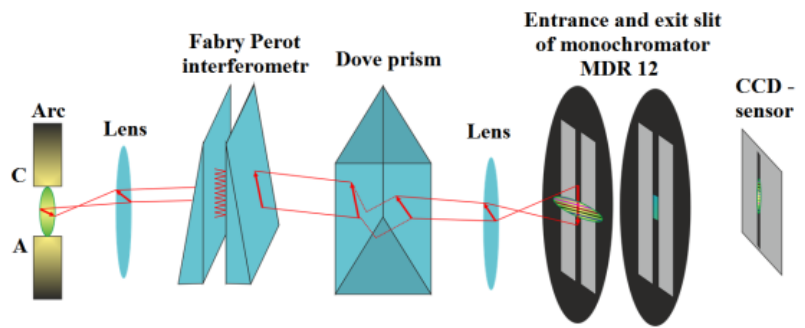

Fig. 2. The optical scheme of experimental setup, based on monochromator, with addition of FPI [17]

\section{RESULTS AND DISCUSSIONS}

At the first stage, the Boltzmann plots were used to select the corresponding Fe I spectral lines, which are sufficient resolved in the registered spectrum (Fig. 3) and will be used in determining the plasma temperature. The modelled spectrum taken from NIST [18] is shown in Fig. 3 as well.

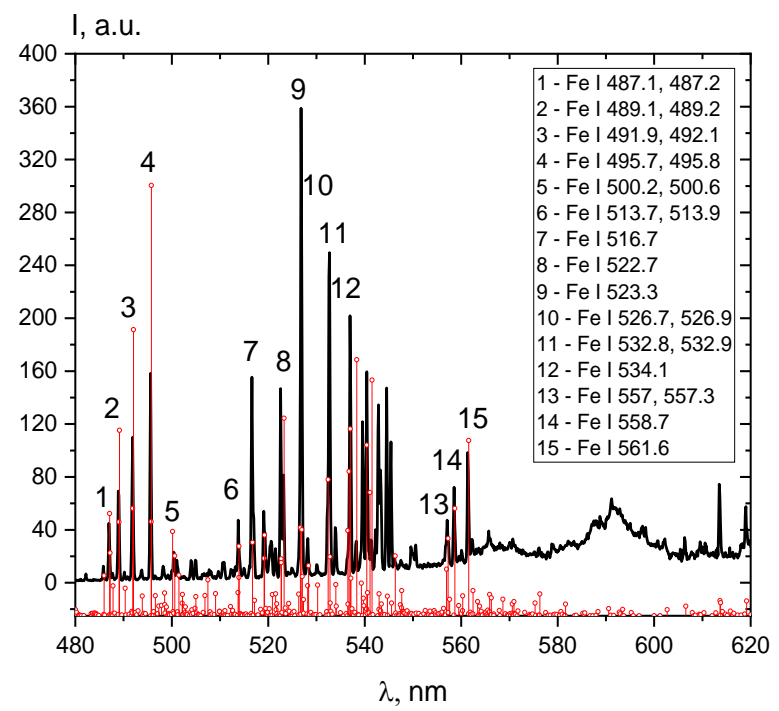

Fig. 3. The emission spectra of electric arc discharge plasma with iron vapours: black line - registered spectrum, red line - modelled spectrum taken from NIST [18]

As one can see, a large amount of Fe I spectral lines are observed in free-burning arc plasma. Previously we studied the plasma of underwater discharges between iron granules [15] as well. It was naturally to use some spectral lines, which were under consideration in that work, with the aim of spectroscopy diagnostic of electric arc discharge plasma in air atmosphere.

Each line was clearly detected, separated and then approximated by Voight function [19]. It should be noted, that intensity of spectral lines with the same energy of upper levels, which cannot be resolved in aproppriate manner due to close wavelength was measured by the another one approach [15]. These lines were approximated by one-peak method and then were used in Boltzmann plot (Fig. 4).
At the next stage the spectral lines, which are most coincinding with an approximating straight line and have a sufficient difference between energy of upper level for Boltzmann plot, were chosen for registration of radial distributions of intesities. The Boltzmann plots on the base of such Fe I spectral lines in different spatial points of discharge arc plasma are shown in Fig. 5.

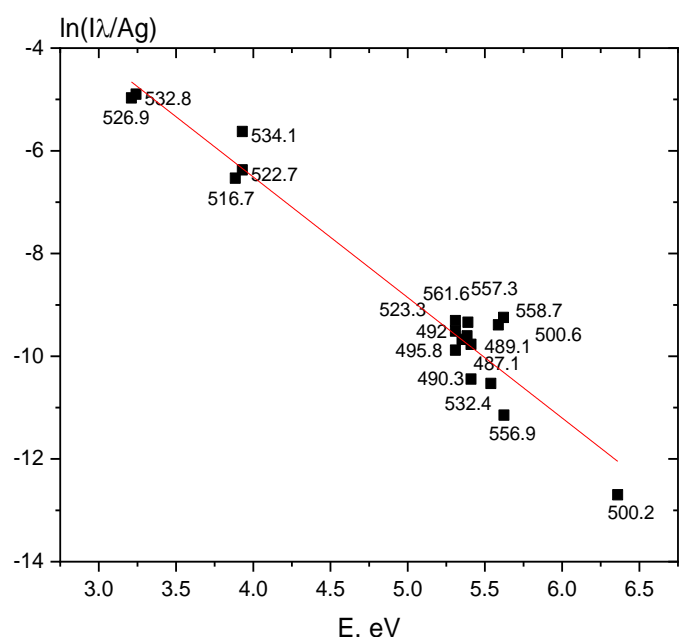

Fig. 4. Boltzmann plot on the base of previously selected Fe I spectral line

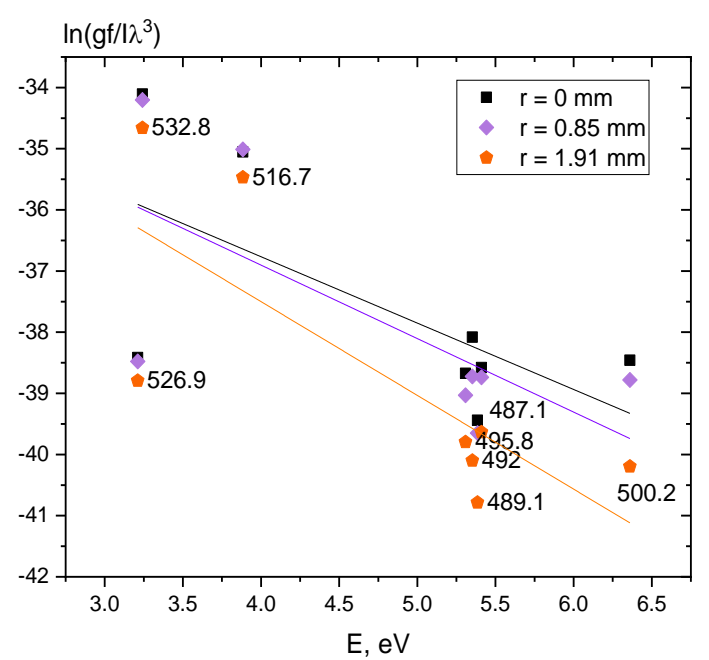

Fig. 5. Typical Boltzmann plots in different spatial points from axis of electric arc discharge plasma

A significant scatter of points relative to the approximating straight line is clearly observed on each plot. This phenomenon can be explained by two reasons. On the one hand, the spectroscopic data, taken from [18], were obtained with significant error $(\sim 25 \%)$. On the other hand, such divergence can be caused by overlapping spectral lines with close wavelengths. The corresponding spatial profile of plasma temperature is shown in Fig. 6.

As it can be found from [15] and Fig. 3, the radiation of plasma with iron vapours is characterised by large amount of spectral lines with close wavelengths. Just due to this, it is necessity to use the experimental setup, where FPI is used as the device with high spectral and spatial resolution for separation of such lines. Contours of each spectral line, which was used in Boltzmann plot (see Fig. 5), were registered and analysed. The typical interferograms of Fe I lines with and without overlapping are shown in Figs. 7-9. It must be noted, that investigations 
of interferograms of spectral lines were carried out at arc current of 3.5 and $30 \mathrm{~A}$ with the aim of clarification of both overlapping and self-reversing of spectral lines profiles.

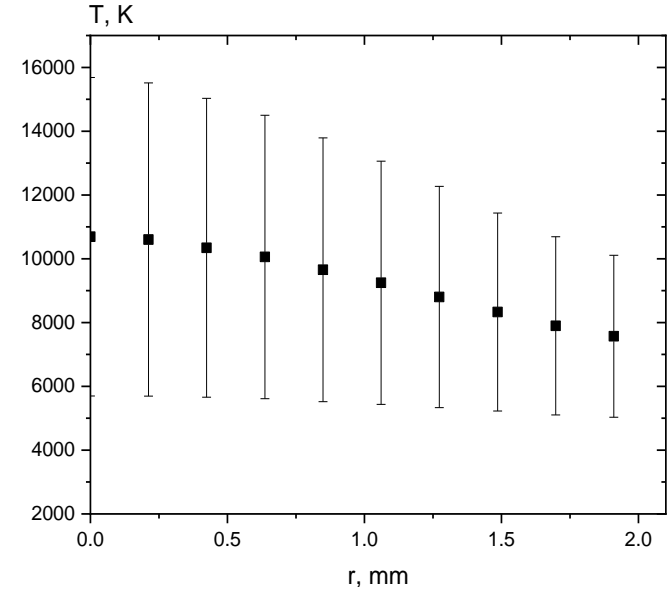

Fig. 6. The radial distribution of plasma temperature, obtained on the base of selected Fe I spectral lines
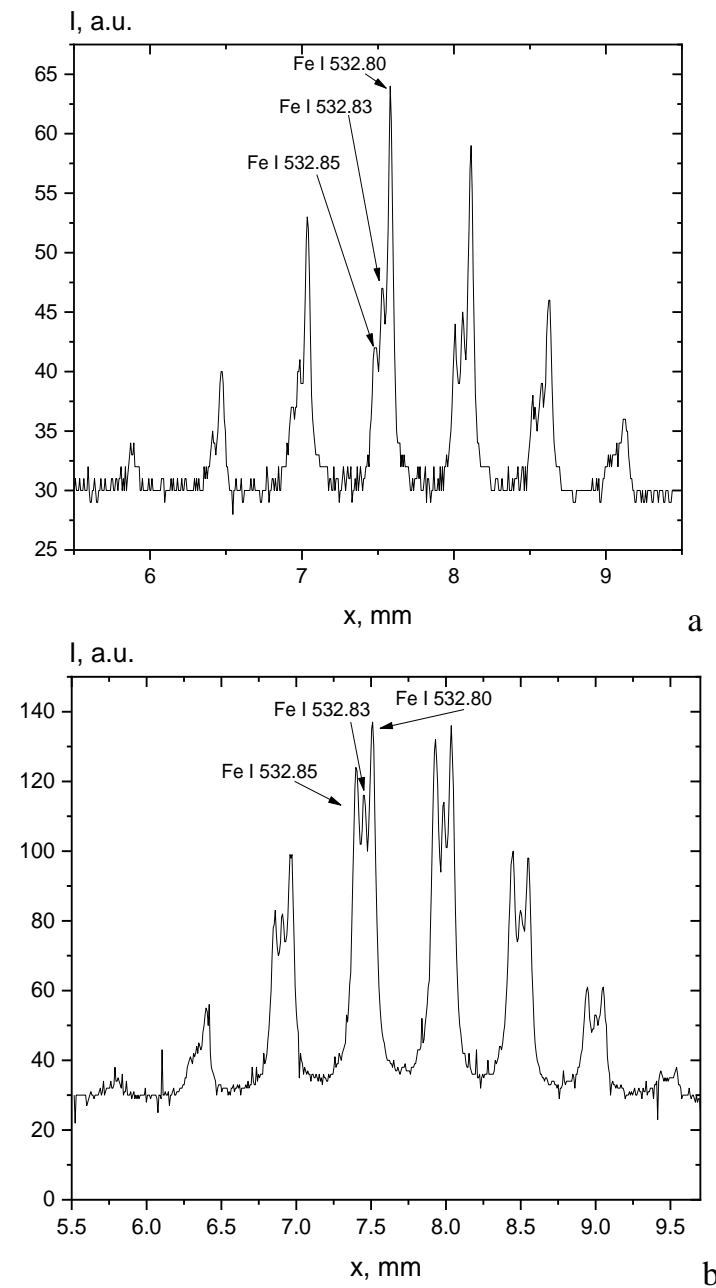

Fig. 7. Registered interferograms of Fe I spectral lines at arc current of $3.5 \mathrm{~A} \mathrm{(a)}$ and $30 \mathrm{~A} \mathrm{(b)}$

As one can see (see Fig. 7), Fe I 532.80 spectral line is overlapped by Fe I 532.83 and $532.85 \mathrm{~nm}$ spectral lines. Therefore, the previously registered emission intensity of the Fe I 532.8 line, which was used in the Boltzmann plot (see Fig. 5), is a total intensity of three lines as it turned out. So, this spectral line as well as other similar lines cannot be used in temperature determination due to its intensity overestimation.
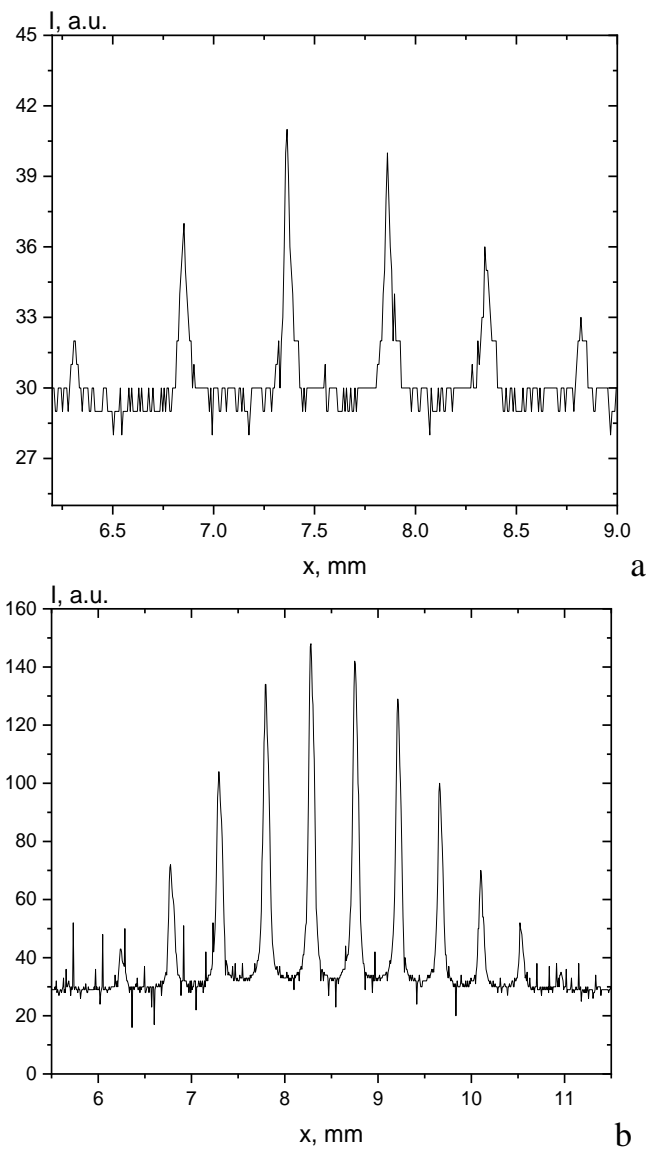

Fig. 8. Registered interferograms of Fe I $495.8 \mathrm{~nm}$ spectral line at arc current of $3.5 \mathrm{~A}(\mathrm{a})$ and $30 \mathrm{~A}(\mathrm{~b})$
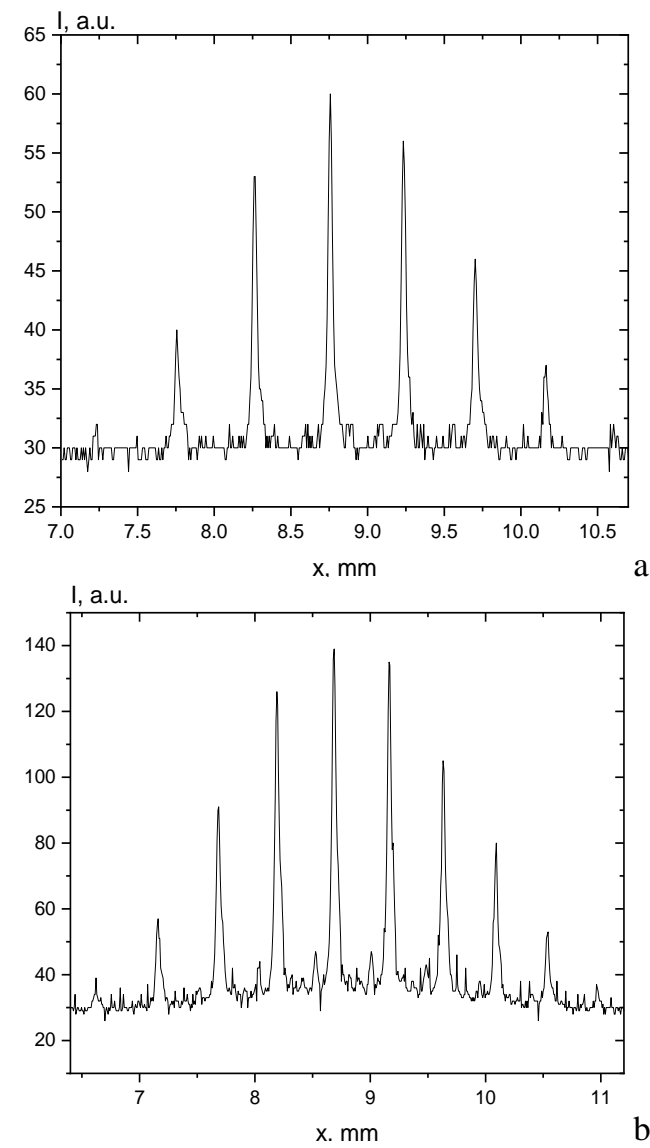

Fig. 9. Registered interferograms of Fe I $516.7 \mathrm{~nm}$ spectral line at arc current of $3.5 \mathrm{~A}(\mathrm{a})$ and $30 \mathrm{~A}(\mathrm{~b})$ 


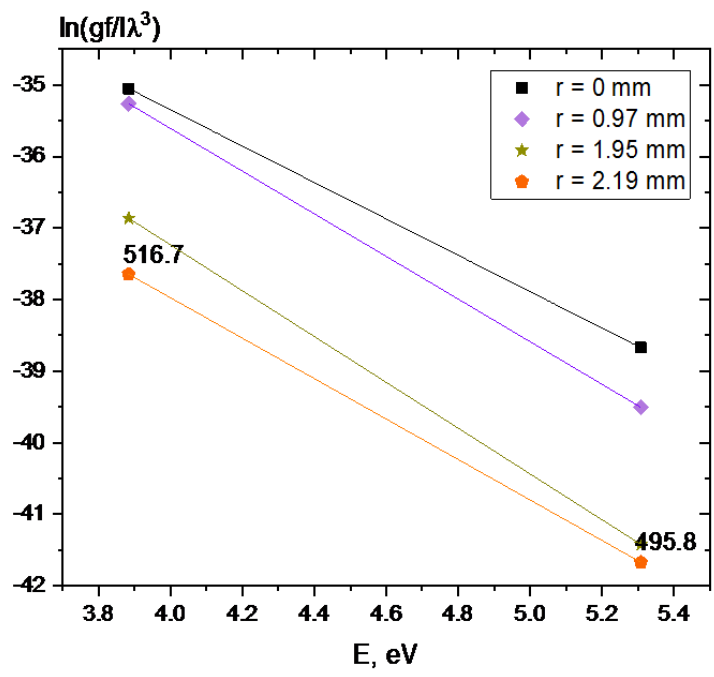

Fig. 10. Typical Boltzmann plots in different spatial points on the base of two isolated Fe I spectral lines

The radial distribution of temperature of electric arc discharge plasma, determined by Boltzmann plot (Fig. 10) on the base of two isolated spectral lines, is shown in Fig. 11. It must be noted, that just these spectral lines can be recommended in the plasma temperature determination by the relative intensities method.

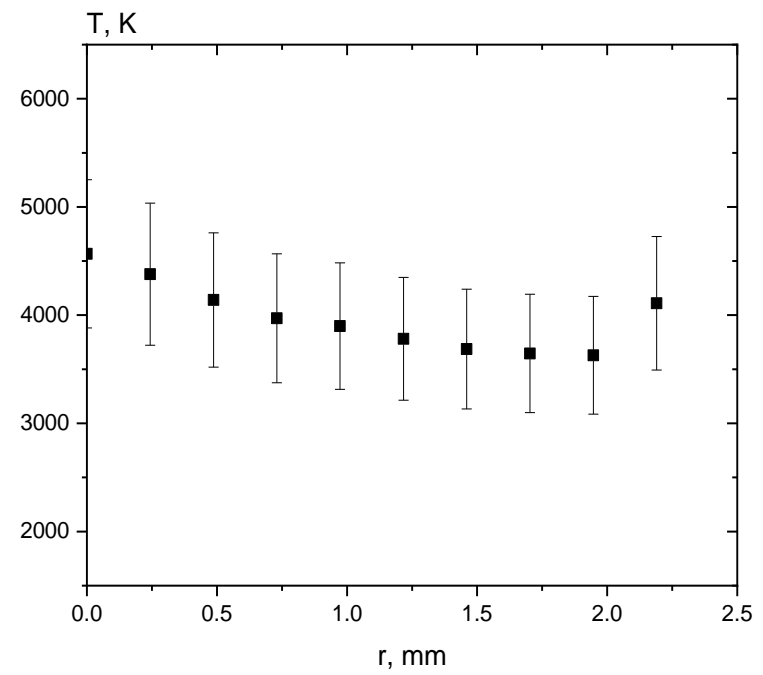

Fig. 11. The radial distribution of plasma temperature, obtained on the base of two isolated Fe I spectral lines

One can see from Figs. 6, 11, the plasma temperature, obtained on the base of two well-isolated spectral lines, is more less in comparison with temperature, obtained on the base of all registered Fe I lines (see Fig. 5). However, the results, shown in Fig. 11, is in more or less agreement with temperature of $6300 \mathrm{~K}$ at the arc axis, obtained for discharge at current of $5 \mathrm{~A}$ and with gap of $2 \mathrm{~mm}$ between iron electrodes [20].

It must be noted, the rising of spatial temperature profile can be explained by deviation from LTE on the arc discharge periphery (radial point of $2.19 \mathrm{~mm}$ ).

\section{CONCLUSIONS}

The spectroscopy peculiarities of electric arc discharge plasma with iron vapours are considered within this investigation. Specifically, the application possibility of Fe I spectral lines as well as determination of plasma temperature were studied by Boltzmann plots technique.

It was found, that spectrum of plasma with iron vapours is complicated due to large amount Fe I spectral lines. The spectral lines of Fe I 495.8 and 516.7 nm can be recommended in the plasma temperature determination, in particular, by the relative intensities method.

\section{REFERENCES}

1. A.B. Murphy. A Perspective on Arc Welding Research: The Importance of the Arc, Unresolved Questions and Future Directions // Plasma Chem. Plasma Process. 2015, v. 35, p. 471-489.

2. A.B. Murphy. The effects of metal vapour in arc welding // J. Phys. D: Appl. Phys. 2010, v. 43(43), p. 434001.

3. J. Wang, Q. Sun, J. Teng, J. Feng. Bubble Evolution in Ultrasonic Wave-Assisted Underwater Wet FCAW // Welding Journal. 2019, v. 98(5), p. 150-163. DOI: 10.29391/2019.98.012

4. H. Jiang et al. High-Speed Tandem Pulsed GTAW of Thin Stainless Steel Plate // Welding Journal. 2019, v. $98(8)$, p. $215-226$.

DOI: https://doi.org/10.29391/2019.98.019

5. X. Yue et al. Technology Development for an Erosion-Resistant Slurry Pipeline Steel // Welding Journal. 2018, v. 97(8), p. 229-242.

DOI: $10.29391 / 2018.97 .020$

6. B. Heider et al. Influence of carbon diffusion on microstructure and wear behaviour of duplex stainless steel surface layers on lamellar grey cast iron // Material wiss. Werkstofftech. 2019, v. 50, p.1165-1180.

DOI 10.1002/mawe.201900129

7. B. Heider et al. Corrosion Resistance and Microstructure of Welded Duplex Stainless Steel Surface Layers on Gray Cast Iron // J. Therm. Spray Tech. v. 29(3), p.1-17.

https://doi.org/10.1007/s11666-020-01003-y

8. A. Mohamadizadeh et al. Spot Weld Strength Modeling and Processing Maps for Hot-Stamping Steels // Welding Journal. 2019, v. 98(8), p. 241-249. DOI: 10.29391/2019.98.021

9. C. Luo et al. Effect of laser heat treatment on bending property of laser welded joints of low-alloy ultra-high strength steel // Journal of Laser Applications. 2019, v. 31(3), p. 032011.

DOI: $10.2351 / 1.5089875$

10. U. Reisgen et al. Improving the corrosion and wear resistance of grey cast iron components by surface welding with duplex stainless steel using regulated gas metal arc welding: Influence of dilution on corrosion properties // Material wiss. Werkstofftech. 2018, v. 49, p. $1520-1537$.

DOI 10.1002/mawe.201800151

11. A. Murmantsev et al. Plasma-surface interaction of electric arc discharge between composite $\mathrm{Cu}-\mathrm{Cr}$ electrodes // Problems of Atomic Science and Technology. 2020, № 6(130), p. 174-178. https://doi.org/10.46813/2020-130-174.

12. A. Murmantsev et al. Thermal Plasma of Electric Arc Discharge Between Composite $\mathrm{Cu}-\mathrm{Cr}$ Electrodes: 
Optical Emission and Electrode Surface Interaction // Plasma Physics and Technology. 2020, v. 7(2), p. 4351.

doi:10.14311/ppt.2020.2.43

13. I.L. Babich et al. Spectroscopic data and Stark Broadening of $\mathrm{Cu}$ I and $\mathrm{Ag}$ I spectral lines: selection and analysis // Advances in Space Research. 2014, v. 54, p. 1254-1263.

14. S. Zielinska et al. Measurement of atomic Stark parameters of many $\mathrm{MnI}$ and Fe I spectral lines usingGMAW process // J. Phys. D: Appl. Phys. 2010, v. 43, p. 434005. doi:10.1088/0022-3727/43/43/434005 15. A. Murmantsev, A. Veklich, V. Boretskij. Excitation temperatures in plasma of underwater discharges between iron granules // Problems of Atomic Science and Technology. 2020, № 6(130), p. 204-207. https://doi.org/10.46813/2020-130-204

16. A. Veklich et al. Regulation of biological processes with complexions of metals produced by underwater spark discharge // Nanooptics and Photonics, Nanochemistry and Nanobiotechnology, and Their Applications. Springer Proceedings in Physics. 2019, v. 247, p. 283-306. https://doi.org/10.1007/978-3-030-52268-1_23

17. R.V. Semenyshyn et al. Spectroscopy peculiarities of thermal plasma of electric arc discharge between electrodes with $\mathrm{Zn}$ admixtures // Advances in Space Research. $2014, \quad$ v. $54, \quad$ p. 1235-1241. http://dx.doi.org/10.1016/j.asr.2013.11.042

18. A. Kramida, Yu. Ralchenko, J. Reader and NIST ASD Team. NIST Atomic Spectra Database (ver. 5.7.1), [Online]. Available: https://physics.nist.gov/asd [2020, October 20]. National Institute of Standards and Technology, Gaithersburg, 2019.

19. A. Murmantsev et al. Hydrogen Balmer Spectral Lines in Spectroscopy of Underwater Electric Spark Discharge Plasma // Contributions of the Astronomical Observatory Skalnaté Pleso. 2020, v. 50, p. 96-104.

https://doi.org/10.31577/caosp.2020.50.1.96

20. F. Burhorn. Temperatur and thermisches Gleichgewicht im Eienbogen // Zeitschrift fur Physik. 1955 , v. 140 , p. $440-451$.

Article received 28.12 .2020

\section{ОСОБЕННОСТИ СПЕКТРОСКОПИИ ПЛАЗМЫ ЭЛЕКТРОДУГОВОГО РАЗРЯДА В ПАРАХ ЖЕЛЕЗА}

\section{А. Мурманцев, А. Веклич, В. Борецкий}

Рассмотрены особенности спектроскопии плазмы электродугового разряда в парах железа. Предложено решение основной задачи оптической эмиссионной спектроскопии, а именно селекции спектральных линий железа, для изучения параметров неоднородного и нестационарного источника плазмы. В частности, метод диаграмм Больцмана использовался для детального анализа и возможности применения спектральных линий Fe I, а также для определения температуры плазмы. Пространственные профили интенсивности излучения выбранных спектральных линий использовались для измерения радиальных распределений температуры плазмы свободно горящего дугового разряда между плавящимися электродами при силе тока дуги 3,5 А.

\section{ОСОБЛИВОСТІ СПЕКТРОСКОПІЇ ПЛАЗМИ ЕЛЕКТРОДУГОВОГО РОЗРЯДУ В ПАРАХ ЗАЛІЗА}

\section{О. Мурманцев, А. Веклич, В. Борецький}

Розглянуто особливості спектроскопії плазми електродугового розряду в парах заліза. Запропоновано вирішення основної задачі оптичної емісійної спектроскопії, а саме селекції спектральних ліній заліза, для дослідження параметрів неоднорідного та нестаціонарного плазмового джерела. Зокрема, метод діаграм Больцмана використовувався для детального аналізу та можливості застосування спектральних ліній Fe I, a також для визначення температури плазми. Просторові профілі інтенсивності випромінювання обраних спектральних ліній використовувались для вимірювання радіальних розподілів температури плазми вільно існуючого дугового розряду між плавкими електродами при силі струму дуги 3,5 А. 